\title{
Analysis of Undergraduate Pharmacology Written (SAQ) Question of Different Universities in Bangladesh
}

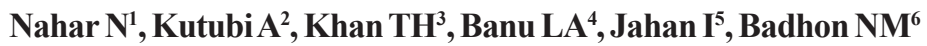

Conflict of Interest: None Received: 13 April 2017

Accepted: 20 May 2017 www.banglajol.info/index.php/JSSMC

Key Words: undergraduate, pharmacology, written, question, assessment

\begin{abstract}
:
Background: Undergraduate medical education aims at sculpting the future physicians. Knowledge gained from here will help them to act effectively when they will face different medical problem in future. It is necessary to ensure that students learn what is important and thus it is very important to assess them with right question in the examination.
\end{abstract}

Methods: This is a retrospective analytical study involving evaluation of $2^{\text {nd }}$ professional $M B B S$ pharmacology written (SAQ) questions held in four universities (Dhaka, Chittagong, Sylhet shahjalal and Rajshahi) of Bangladesh. Written (SAQ) question from July 2008 to July 2016 were analyzed for content coverage, type of question, educational objectives as per 2002 curriculum.

Results: Total 56 written questions were analyzed. Each question contains 24 items SAQ arranged in four groups. On the basis of content coverage chemotherapeutic (19\%), CNS (16\%), GP (15\%) and ANS(10\%) are the maximum weightage of content area. Some aspect which are clinically important but less practiced in written examination are GIT, respiratory, renal, hemopoietics, lipid lowering agents and miscellaneous. Though the entire question should be SAQ type but some (4\%) portion of question became essay type and short notes (5-10\%) also common. Most of the questions were recall (90\%) type, problem solving questions only $2 \%$.

Conclusion: It can be concluded that assessment instrument should be based on structured guidelines to improve the quality of question. To maintain consistency among different university periodic analysis of written questions, test blue printing and table of specification may be used.

[J Shaheed Suhrawardy Med Coll 2017; 9(1): 13-17] DOI: http://dx.doi.org/10.3329/jssmc.v9i1.37253

\section{Introduction:}

Medical education is the art and science behind medical learning and teaching has progressed remarkably. During the last three decades medical school have been faced with a variety of challenges from society, patients, doctors and students. They have responded in several ways includimg the development of new curricula, the introducing of new learning methods and new method of assessment ${ }^{1}$.

The assessment procedure has a powerful positive steering effect on learning and the curriculum ${ }^{2}$. Scientific studies

1. Prof. Dr. Nurun Nahar, Professor and Head, Pharmacology Department, MH Samorita Hospital and Medical College.

2. Dr. Afroza Kutubi, Associate Professor, Department of Obst. \& Gynae, Dhaka Medical College

3. Dr. Md. Tafazzal Hossain Khan, Associate professor, Department of Neonatology, Dhaka Medical College, Dhaka.

4. Prof. Dr. Layla Afroza Banu, Professor and Head, Pharmacology Dept. ZH Sikder Women's Medical College, Dhaka

5. Dr. Israt Jahan, Assistant Professor, Pharmacology Department MH Samorita Hospital and Medical College.

6. Dr. Nazia Mahmud Badhon, Assistant Professor, Pharmacology Department, MH Samorita Hospital and Medical College.

Address of correspondence: Prof. Dr. Nurun Nahar, Professor and Head, Pharmacology Department, MH Samorita Hospital and Medical College, E-mail: nurunnahar004@gmail.com confirm that it is the evaluation process rather than the educational objectives or curriculum or instructional techniques that have the most profound impact on what the students ultimately learn ${ }^{3}$.

Over the past decade many effort have made to provide accurate reliable and timely assessment of the competence of trainees and practicing physicians 4,5,6. Such assessment have three main goals: to optimize the capabilities of all learners and practitioners by providing motivation and direction for future learning, to protect the public by identifying incompetent physician and provide a basis for choosing applicants for advanced training.

Assessment can be formative or summative. Formative assessment reinforce students intrinsic motivation to learn and inspire them to set higher standards for themselves. On the otherhand summative assessment are intended to provide professional self regulation and accountability they may also act as a barrier to further practice or training. In summative assessment students tends to study that which they expect to be tested on and it influenced learning even in the absence of feedback ${ }^{7}$. 
The use of a variety of different assessment method has been characteristics of medical education since 1950. All method of assessment has strengths and intrinsic flaws. The use of several different methods over time can partially compensate flaws in any one method. The written examination question usually composed of open ended questions of one type or another which were graded by hand $^{2}$.

As the assessment procedures have a powerful influence over learning process ${ }^{8}$ and students usually concentrate their studies on what is asked or what could be asked in the examination. As teacher it is our duty to guide them towards proper learning and to apply this in practice. In this way we also indirectly protect the public from improper practice of the future physicians ${ }^{7}$. As such our examination question should be in proper direction.

Assessment should match the content of the course and should provide proportional weightage to each of the content ${ }^{9}$. On the otherhand it should also match the objectives of course. As assessment drives learning hence it is important to ask the right questions in examination. Thus question papers in the form of a written examination form a very important tool of the assessment ${ }^{10}$.

Written examination mainly aims at assessing the knowledge where as viva voce and practical examination are clinically oriented ${ }^{11}$. Various types of written question can be used like MCQ, SAQ, MEQ, SEQ. In the past long essay question were commonly used in written examination to assess the cognitive ability of students. But this traditional essay question could not yield the expected answers and wide variation in student's interpretation was noted. Therefore it is showed limited validity, poor reliability and less objectivity ${ }^{12}$. On the otherhand SAQ direct the students towards a precise and specific response and provide greater objectivity, reliability and their range of content area testes is extend ${ }^{13}$.

In Bangladesh during the 2002 curriculum question pattern was changed in written examination and MCQ and SAQ was introduced in written examination for better content coverage. It was seen that different university under same curriculum prepare question for written examination in different format. In our country only one study ${ }^{14}$ was found on focusing undergraduate pharmacology written question evaluation has been carried since 2002 curriculum. Therefore the present study was done with the aim to analyze the pharmacology written question (SAQ) held under different universities regarding content coverage, type of question and objectives of course.

\section{Methods :}

This is a retrospective analytical study. Total 56 written questions (SAQ) held under four university (Dhaka, Chittagong, Sylhet Shahjalal, Rajshahi) from July 2008 to July 2016 were collected. All questions were set for $2^{\text {nd }}$ professional MBBS pharmacology written examination according to curriculum 2002. Total Marks were 70 and time was two and half hour. The examination was carried out two times January and July each year. Each question contains 24 items arranged in four groups A, B, C, D on different topics. Each group contains six items from which students should answer five from each group with one alternative/option. Analysis of question item was done on the basis of their frequency of occurrence according to content coverage, type of question (SAQ, essay, short note), level of knowledge domain, specificity, printing mistakes, non-pharmacological questions etc. Findings after analysis were expressed as percentage and shown in table and figure.

\section{Results :}

Total 56 written questions from four public university were collected . 17 question papers from Dhaka university, 14 papers from Chittagong university, 10 papers from Sylhet Shahjalal university and 15 papers from Rajshahi university were included for analysis. Each question contains 24 items arranged in four groups (A, B, C, D) and total 1344 items of SAQ were evaluated. The questions of Dhaka university was categorized as group 1, Chittagong university was grouped as group II, Sylhet Shahjalal university wasgrouped as group III and Rajshahi university was grouped as group IV.

Analysis of item of question on the basis of content coverage revealed that chemotherapeutic (19\%), Central nervous System (CNS) (16\%), General Pharmacology(GP) (15\%) and Autonomic Nervous System (ANS) (10\%) are the maximum weightage of content area in question. Some aspect which are clinically important but less practiced in written question are gastrointestinal, respiratory, renal, blood, lipid lowering agents and miscellaneous. (Table-1)

According to 2002 curriculum written examination question should be SAQ type of 70 marks but study reveals that some $(2-7 \%)$ portion of question became essay type and $5-10 \%$ were short notes in all universities (Table 2, figure $1)$.

Considering educational domain most of the questions were recall type (84-91\%), understanding type questions were $5 \%$, application type question were $4 \%$ and problem solving questions only $2 \%$. Percentage of non specific (non pharmacological) question, ambiguous language, inadequate marks distribution, printing mistake was common in all universities range from 1 to 7 percent. (Table 3 , figure 2). 


\section{Table 1}

\begin{tabular}{|c|c|c|c|c|c|}
\hline \multirow[b]{2}{*}{ Content } & weightage $c$ & ontent in ques & among four & versities & \multirow[b]{2}{*}{$\begin{array}{c}\text { Total } \\
\mathrm{N}=1344\end{array}$} \\
\hline & $\begin{array}{c}\text { Dhaka } \\
\text { university } \\
(\mathrm{G}-\mathrm{I}) \\
\mathrm{N}=408\end{array}$ & $\begin{array}{c}\text { Chittagong } \\
\text { university } \\
\text { (G-II) } \\
\mathrm{N}=336\end{array}$ & $\begin{array}{c}\text { Shahjalal } \\
\text { university } \\
\text { (G-III) } \\
\mathrm{N}=240\end{array}$ & $\begin{array}{c}\text { Rajshahi } \\
\text { university } \\
\text { (G-IV) } \\
\mathrm{N}=360\end{array}$ & \\
\hline Chemotherapeutics & 21 & 19 & 19 & 17 & 19 \\
\hline Central nervous system (CNS) & 17 & 18 & 16 & 13 & 16 \\
\hline General pharmacology(GP) & 15 & 16 & 14 & 14 & 15 \\
\hline Autonomic nervous system (ANS) & 10 & 07 & 11 & 10 & 10 \\
\hline Cardiovascular system (CVS) & 08 & 11 & 10 & 09 & 09 \\
\hline Endocrine & 06 & 10 & 10 & 08 & 08 \\
\hline Renal & 04 & 03 & 02 & 04 & 03 \\
\hline Autacoids & 04 & 04 & 03 & 05 & 06 \\
\hline NSAIDs & 02 & 02 & 03 & 05 & 03 \\
\hline Gastro intestinal (GIT) & 03 & 03 & 03 & 03 & 03 \\
\hline Respiratory & 02 & 03 & 03 & 04 & 03 \\
\hline Blood & 04 & 03 & 03 & 05 & 03 \\
\hline Miscellaneous & 04 & 02 & 03 & 03 & 03 \\
\hline
\end{tabular}

Table-II

Type of question in four universities by percentage

\begin{tabular}{lcccc} 
& Dhaka university & Chittagong & Sylhet Shahjalal & Rajshahi \\
Question & $(\mathrm{G}-\mathrm{I})$ & university (G-II) & university (G-III) & university (G-IV) \\
type & $\mathrm{N}=408$ & $\mathrm{~N}=336$ & $\mathrm{~N}=240$ & $\mathrm{~N}=360$ \\
SAQ & 96 & 95 & 93 & 98 \\
Essay & 04 & 05 & 07 & 02 \\
Short notes & $10 \%$ & $1 \%$ & $5 \%$ & $5 \%$ \\
\hline
\end{tabular}

\section{Table-III}

Level of knowledge domain and specificity of question in four universities by percentage

\begin{tabular}{lcccc}
$\begin{array}{l}\text { Level of } \\
\text { knowledge }\end{array}$ & $\begin{array}{c}\text { Dhaka } \\
\text { university (G-I) } \\
\text { domain }\end{array}$ & $\begin{array}{c}\text { Chittagong } \\
\text { university (G-II) }\end{array}$ & $\begin{array}{c}\text { Sylhet Shahjalal } \\
\text { university (G-III) }\end{array}$ & $\begin{array}{c}\text { Rajshahi } \\
\text { university (G-IV) }\end{array}$ \\
\hline Recall & 91 & $\mathrm{~N}=336$ & $\mathrm{~N}=240$ & $\mathrm{~N}=360$ \\
Understanding & 03 & 81 & 09 & 07 \\
Application & 02 & 03 & 06 & 07 \\
Problem based & 01 & 03 & 05 & 05 \\
Non specific, ambiguous language, & 03 & 04 & 07 & 01 \\
printing mistakes, inadequate marks & & & & 02 \\
\hline
\end{tabular}




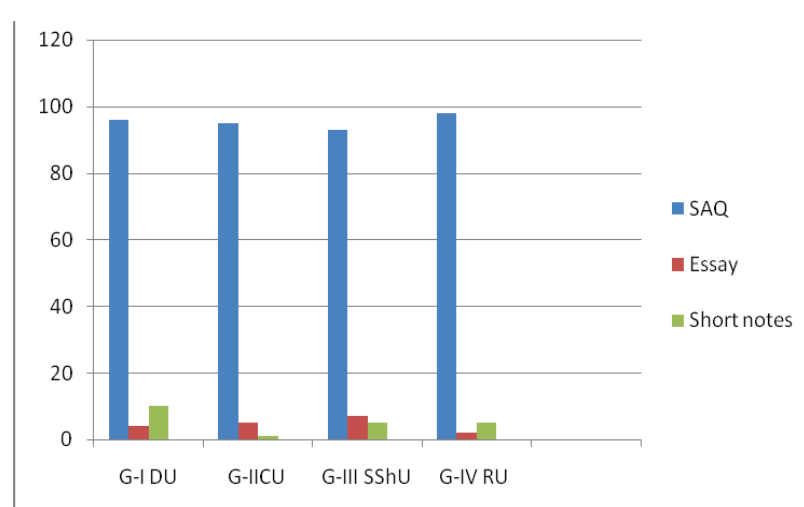

Figure 1: Bar diagram showing type of question in four universities.

\section{Discussion:}

Assessment is the process of gathering information on students learning ${ }^{10}$ and are important component of teaching and learning. What is assessed, how it is done and how the results are communicated send a clear message to students about what is really valued, what is worth learning, how it should be learnt, what element of study are most important and how well students are expected to learn. ${ }^{10}$

This study was done to find out the content coverage, type of question and educational objectives sets in pharmacology written (SAQ) examination held under four universities of same curriculum.

According to content coverage it was revealed that chemotherapeutic (19\%), CNS (16\%), GP (15\%) and ANS $(10 \%)$ are the maximum weightage of content area. This findings are partially related to findings to Narvekar et al 10 where they found that ANS, CVS in paper I and chemotherapeutic and CNS topic in paper II are highest percentage of topic included in written examination. In another study Chowdhury et al ${ }^{14}$ also found that topic in $\mathrm{CNS}$, chemotherapeutic, ANS and GP are highest. Certain topics like renal, GIT, respiratory, blood, autacoids and NSAIDs given less importance in written examination in all universities.

Similar studies done in other subjects in Rajasthan and Pondicherry 15,16 also impress upon the requirement of guidelines for proper distribution of weightage to the content areas. in written examination. It is important that while setting a paper the topics should be selected based on practical importance and rare and unusual topics can be avoided to lessen student's burden of learning.

Allocation of weightage to various topics usually depends on two criteria - (i) the perceived impact/importance of a topic in terms of its impact on health and (ii) The frequency

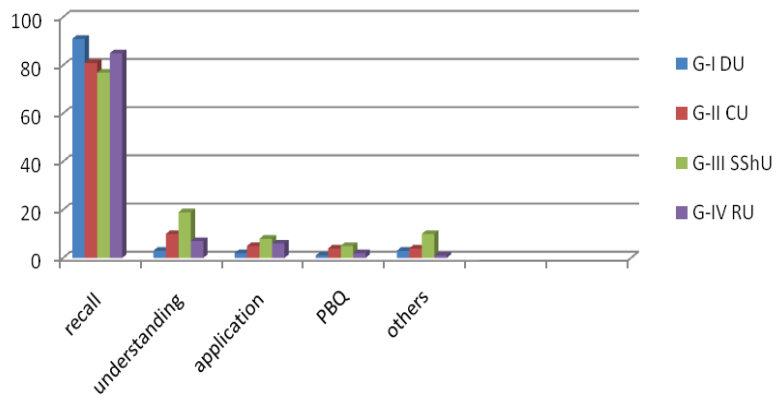

Figure 2: Bar diagram showing educational domain in written $(S A Q)$ question in four universities.

of occurrence of a particular disease or the health problem. 17 Thus consistency can be ensured if there are set guidelines for marks distribution to the topics, based on which papers can be set.

By comparison type of questions it was found that SAQ were higher percentage but there were 2 to 7 percent questions were essay type and 5-10\% were short notes in all universities. According to 2002 curriculum all question should be SAQ so emphasis should be given to introduce all question should be SAQ type.

According to educational domain questions should be all type like, recall, understanding, application and problem solving. But in this study we observed that highest percentage of questions are recall in all universities i.e 80 to 90 percent. This findings are similar to othrer observations ${ }^{14,18}$ Understanding type of questions were only 5 percent, application type were 4 percent and problem solving questions only 2 percent.

There should be fixed criteria as written document for setting questions for the written examinations that fulfill the objectives of the course. ${ }^{19}$ Blueprinting and good sampling of the content is very helpful to ensure proper content coverage, objectives and type of question selected for written examination.

A test blueprint and table of specification provides a template for the question paper setter and the examiner to assess all that is expected from a student at the end of a learning session. It specifies the content areas / topics, the domains of learning and the appropriate methods or tools of assessment ${ }^{20}$. Therefore it serves as a reference framework for the question paper setter to prepare questions according to curriculum and accepted guidelines.

\section{Conclusion:}

It can be concluded that there is difference in type of question and content coverage in written examination of 
pharmacology among universities in Bangladesh. Structured guidelines for question setters and methods like test blueprinting and table of specification may be used for consistency of validity and quality of written question. Also periodic analysis of assessment techniques by the faculty, look for any lacunae and improve upon those lacunae may give proper direction to improve the situation.

\section{References:}

1. Tabish SA. Assessment methods in medical education. Int $\mathbf{J}$ of Health Sci. (Qassim) 2008; July 2(2): 3-7.

2. Norcini JJ, McKinley WD. Assessment methods in medical education.Teaching and Teacher Education. 2007; 23: 239250.

3. Miller G E. assessments in Medical School. Med Educ 1976; 10: $79-80$.

4. Epstein RM, Hundert EM. Defining and assessing professional competence. JAMA 2002; 287: 226-35.

5. Batalden P, Leach D, Swing S, Dreyfus H, Dreyfus S. General competencies and accreditation in graduate medical education. Health Aff (Millwood) 2002;21(5):103-11.

6. Leung WC. Competency based medical training: review. BMJ 2002; 325: 693-6

7. Epstein RM, Assessment in medical education. $N$ Engl $J$ Med. 2007; 356(4): 387-96.

8. Miller G E. Educational Strategies for the Health Professions. In: Developments of Educational Programmes for the Health Professionals WHO Public Health papers No. 52, 1973.

9. Tejinder S. Basics of assessment. In: Tejinder S, Anshu, editors. Principles of assessment in medical education. India: Jaypee Brothers Medical Publishers; 2012: 1-13.

10. Narvekar RS, Nikhil N. Bhandare, Padma N. Bhandare. Analysis of undergraduate pharmacology question papers at Goa medical college as regards to their content areas. Int $J$ Sci Rep. 2016 Aug;2(8):182-186. http://www.sci-rep.com

11. Anshu. Assessment of knowledge:Written assessment. In: Tejinder S, Anshu, editors. Principles of assessment in medical education. India: Jaypee Brothers Medical Publishers; 2012: 70-79.

12. Paul VK. Essay Questions. In: Sood R, Paul VK, Sahni P, Mittal S, Kharbandra OP, Adkoli BV. editors. Assessments in Medical Education, trend and tools. New Delhi: K. L. Wig Centre for Medical Education and Technology, 1995, p 1725.

13. Sabherwal U. Short Answered Questions. In: Sood R, Paul VK, Sahni P, Mittal S, Kharbandra OP, Adkoli BV. editors. Assessments in Medical Education, trend and tools. New Delhi: K. L. Wig Centre for Medical Education and Technology, 1995, p 27-31.

14. Chowdhury DKP, Saha D, Talukder HK, Habib MA, Islam AFMS, Ahmad R, Hossin I. Evaluation of Pharmacology Written Question Papers of MBBS Professional Examinations. Bangladesh Journal of Medical Education. Vol.08, Issue- 02, 2017.

15. Rohin G, Dhiraj S, Sushila S, Neha D. Analytical study of written examination papers of undergraduate anatomy: Focus on its content validity. IJBAMR. 2013;2(8):1110-6.

16. Ananthakrishnan N, Ananthakrishnan S, Oumachigui A. MBBS examinations - are we asking the right questions. J Postgrad Med. 1993;39:31.

17. Sylvain C, Wayne W, Kevin M, Twelve tips for blueprinting. Med Teach. 2009;31:322-4.

18. Sindhu, S, Singh, HK, Saiman, MT \& Verma, VK 2011. 'Comparative Evaluation of Pharmacology Question Papers in Medical Colleges Affiliated to Different Universities in North India along with Recommendation'. Journal of research in Medical Education \& Ethics,1(3),180-186.

19. Ali T, Begum N, Begum AA, Shamim KM, Ferdousi S, Bennoor KS Summative Assessment (Written) in Undergraduate Physiology Curriculum in Bangladesh: Reflection of Educational Objective. J Bangladesh Soc Physiol.2008 Dec;(3):61-65. http://www.banglajol.info/index.php/JBSP

20. Adkoli BV, Deepak KK. Blueprinting in assessment. In: Tejinder S, Anshu, editors. Principles of assessment in medical education. India: Jaypee Brothers Medical Publishers; 2012: 215-213. 